\title{
Complementarity and efficiency of bat capture methods in a lowland tropical dry forest of Yucatán, Mexico
}

\section{Complementariedad y eficiencia de métodos de captura de murciélagos en una selva baja caducifolia de Yucatán, México}

\author{
Juan M. Pech-Canche ${ }^{1 *}$, Erendira Estrella ${ }^{2}$, Diana L. López-Castillo ${ }^{2}$, Silvia F. Hernández-Betancourt ${ }^{2}$ and \\ Claudia E. Moreno ${ }^{3}$ \\ ${ }^{1}$ Red de Ecoetología, Instituto de Ecología, A.C. Apartado postal 63, 91000 Xalapa, Veracruz, México. \\ ${ }^{2}$ Departamento de Zoología, Campus de Ciencias Biológicas y Agropecuarias, Universidad Autónoma de Yucatán. Apartado postal 4-116 Itzimná, \\ 97000 Mérida, Yucatán, México. \\ ${ }^{3}$ Centro de Investigaciones Biológicas, Universidad Autónoma del Estado de Hidalgo, Apartado postal 69-1, 42001 Pachuca, Hidalgo, México. \\ ${ }^{*}$ Correspondent: jmpech@gmail.com
}

\begin{abstract}
Resumen. El uso combinado de diferentes métodos de muestreo de ensambles de murciélagos se ha incrementado en las últimas décadas. El objetivo de este estudio fue evaluar la eficiencia de los inventarios de murciélagos comparando los parámetros del ensamble (riqueza de especies, abundancia y composición) usando los 3 métodos de captura convencionales (redes de niebla a nivel de sotobosque y sub-dosel, y trampas arpa), en una selva baja caducifolia de Yucatán, México. En las redes de sotobosque se registraron solamente especies de filostómidos, principalmente especies frugívoras y nectarívoras; mientras que en las trampas arpa, la mayoría fueron especies insectívoras de otras familias. Nuestros resultados indican que para el orden Chiroptera la combinación más eficiente de métodos de captura es el uso simultáneo de redes de sotobosque y trampas arpa. Sin embargo, se alcanza un inventario confiable de filostómidos sólo con las redes de sotobosque. Además, una combinación de redes de sotobosque y sub-dosel no provee una eficiente estrategia de muestreo.
\end{abstract}

Palabras clave: inventarios de biodiversidad, Chiroptera, redes de niebla, trampas arpa, selva baja caducifolia, Yucatán.

\begin{abstract}
The combined use of different methods for surveying bat assemblages has increased over the last few decades. The objective of this study was to assess the efficiency of bat inventories by comparing assemblages parameters (species richness, abundance and composition) using the 3 most conventional capture methods (ground-level and sub-canopy mist nets and harp traps), in a lowland tropical dry forest in Yucatán, Mexico. In ground mist nets, only phyllostomid species were recorded, principally frugivorous and nectarivorous species, while in harp traps the majority were insectivorous species from other families. Our results indicate that for the order Chiroptera the most efficient combination of capture methods is the simultaneous use of ground mist nets and harp traps. However, an inventory of Phyllostomidae is reliably achieved with only ground mist nets. Also, a combination of ground and sub-canopy mist nets does not provide an efficient sampling strategy.
\end{abstract}

Key words: biodiversity inventories, Chiroptera, mist nets, harp traps, lowland tropical dry forest, Yucatán.

\section{Introduction}

Adequate inventory efforts are the basis of our knowledge of species diversity at any given site. For bats, a variety of direct capture methods have been developed, among which mist nets and harp traps are the best known. Mist nets are practical for capturing the slower-flying species, which have a more manoeuvrable flight and emit lower frequency calls. They may be placed at different heights and orientations under a variety of conditions,

Recibido: 01 marzo 2010; aceptado: 11 febrero 2011 from open to cluttered spaces, in vegetated areas or water bodies. Harp traps are useful for capturing fast-flying, lessagile species that emit high frequency calls and can be used in more restricted situations such as the entrance of a cave or within dense vegetation (Wilson et al., 1996; Berry et al., 2004). Indirect techniques (i.e., ultrasonic detectors) enable the detection of species that are difficult to capture (O'Farrell and Gannon, 1999; MacSwiney et al., 2006).

Recently, different sampling protocols have been developed and evaluated to improve the quality of bat inventories, including: the comparison of different horizontal (Carroll et al., 2002) and vertical (Bradshaw, 1996; Kalcounis et al., 1999; Bernard, 2001) arrangements 
of nets, the assessment of different sampling efforts (Esbérard and Bergallo, 2008), the comparison of different net check schedules (MacCarthy et al., 2006), the evaluation of different types of ultrasonic detectors (Fenton et al., 2001; Johnson et al., 2002; Milne et al., 2004) and their spatial orientation in forest interiors (Weller and Zabel, 2002), as well as the consideration of serious issues related to mist net bias (Larsen et al., 2007). Even the combined use of different techniques has been explored, such as: the comparison between different capture and acoustic detection methods (Kuenzi and Morrison, 1998; O'Farrell and Gannon, 1999; MacSwiney et al., 2008), the comparison between a variety of capture methods (Francis, 1989), and the combination of capture, indirect registration and roosting site searches (Mora et al., 2002; Flaquer et al., 2007).

The objective of this study was to assess the efficiency of 3 conventional capture methods (ground-level and sub-canopy mist nets, and harp traps) to adequately describe assemblage parameters. Efficiency was defined as the ability to represent the maximum species diversity in samples with the minimum sampling time and effort. The particular objectives of this study were to compare different estimates of richness, abundance, and composition of a tropical bat assemblage which result from the use of different capture methods, and to analyze the complementarity between capture methods. The study was carried out in an area of deciduous lowland tropical dry forest in the north of the Yucatán Peninsula, Mexico. We predicted that the simultaneous use of 2 or 3 of these methods would be more efficient, allowing the detection of greater species richness than that recorded by any of the capture methods used alone.

\section{Materials and methods}

Study area. The study was carried out in the Dzibilchaltun National Park, in northwestern Yucatán, Mexico $\left(21^{\circ}\right.$ $05^{\prime} 32.4^{\prime \prime} \mathrm{N}, 89^{\circ} 35^{\prime} 51.4^{\prime \prime} \mathrm{W}$ ) which covers a total area of 539 ha. Regional climate is hot and sub-humid with annual precipitation between 700 and $900 \mathrm{~mm}$, with a rainy season from May to October and a dry season from November to April. The mean annual temperature is 28 ${ }^{\circ} \mathrm{C}$, with the maximum temperature reaching $40{ }^{\circ} \mathrm{C}$ (Duch, 1988; SECOL, 1993).

The vegetation type is lowland tropical dry forest, with tree heights ranging from 10 to $15 \mathrm{~m}$, and the leguminous family being dominant. The oldest trees reach a diameter at breast height (DBH) of nearly $40 \mathrm{~cm}$, although the $\mathrm{DBH}$ of the majority of trees is between 10 and $30 \mathrm{~cm}$. At the interior of the study site there is an ellipsoid-shaped water body (cenote in Mayan), with a surface area of $60 \mathrm{~m}^{2}$ and a depth of $0.5 \mathrm{~m}$ at its eastern edge and $45 \mathrm{~m}$ at its western edge (SECOL, 1993).

Bat Capture. Sampling was carried out in 2 consecutive nights each month from November 2005 to October 2006, avoiding the full moon (Morrison, 1978), rain, or strong winds. To capture bats, we placed 3 mist nets at ground level and 3 mist nets at $8 \mathrm{~m}$ above ground level (sub-canopy), all of which were $12.0 \mathrm{~m}$ long by $2.6 \mathrm{~m}$ high with a $36 \mathrm{~mm}^{2}$ mesh, as well as 2 four-line harp traps (Francis, 1989) that were $1.0 \mathrm{~m}$ wide by $1.2 \mathrm{~m}$ high. On each evening, the 6 mist nets and 2 harp traps remained open during a 6 hour period after dusk, and were monitored every $30 \mathrm{~min}$. The mist nets were placed along open pathways within the forest around the cenote, while the harp traps were also placed around the cenote but in more restricted cluttered areas within the vegetation, however, because bats are able to detect where the nets are placed (Winhold and Kurta, 2008), the nets were moved a few meters each sampling night, but placed in a site with the same vegetation structure. Captured individuals were marked with colour coded plastic collars for individual identification (sensu Medellín et al., 2000), and released at the capture site within a period of less than 2 hours after capture.

The capture rate was estimated following the method proposed by Findley and Wilson (1983), that is, by dividing the number of species or individual bats captured per night per net or trap (BNN or BNT), because although we used the same sampling design during all nights, the different size of nets and traps represent an inherent bias due to the differential setting area. Therefore, we use BNN or BNT rather than the traditional measure of sampling effort (length of mist nest by hours) (Medellín, 1993), to prevent unwarranted variation and a false precision of the data (Pedersen et al., 2005). Taking into account that bats tended to follow trails, both in open pathways or more cluttered areas, the area-level comparison may not be justified because the area of each net is similar to that of each trap over a trail (Francis, 1989).

Comparison of assemblage parameters among capture methods. To compare the species richness recorded among capture methods, we used 2 different measures: 1), total richness (accumulated alpha diversity), which is the total number of species recorded throughout the entire study, and 2), mean punctual richness (mean alpha diversity), which is the mean number of species recorded on each of the nights sampled. To analyze the total richness recorded with each capture method, we performed rarefaction curves, which were based on number of individuals as a measure of sampling effort to avoid confounding genuine differences in species richness with differences in trap efficiency (Willot, 2001), and randomized 1000 times to eliminate the influence of the order in which individuals 
are added to the total. We also calculated Chao indices as estimators of the maximum expected richness, as these indices assume homogeneity of the habitats sampled (Magurran, 2004). The comparison of total richness was carried out by standardizing at the lowest abundance recorded on each single method. The rarefaction curves and the estimators of maximum expected richness were both carried out with EstimateS, version 7.5 (Colwell, 2005). To test whether there were differences in the mean point richness and the bat capture rate between capture methods, we used the non-parametric Kruskal-Wallis $(\mathrm{H})$ test (Zar, 1999) as the data were not normally distributed, using captures rates by net/trap by night as replicates. Given that there are no post-hoc tests available with this test we used paired comparisons between methods using the Bonferroni test to correct the level of significance (Rice, 1989). These tests were carried out using the programme $\mathrm{R}$ version 2.8.1 (R Development Core Team, 2008).

Species were classified into broad trophic guilds according to diet and foraging behaviour (Simmons and Voss, 1998): 1), aerial insectivores (all non phyllostomids), 2), frugivores (carolliines and stenodermatines), 3), nectarivores (glossophagines), and 4), sanguivores (desmodontines). Given that phyllostomines were represented only by a single individual, the trophic guild of gleaning animalivore was excluded from this analysis. To test for differences in the proportion of guilds recorded using each capture method, we carried out a $G$ test for contingency tables (Zar, 1999).

Complementarity between capture methods. To analyze the total richness recorded by combinations of capture methods we carried out rarefaction curves, with the same procedure of those with single methods, for all possible combinations of 2 capture methods and for the combination of the 3 capture methods, with the idea of identifying the combination that recorded the maximum total species richness. The rarefaction curves were carried out with EstimateS, version 7.5 (Colwell, 2005). The comparison of total richness was carried out by standardizing the lowest abundance recorded in any combination of the methods.

The complementarity between capture methods was evaluated at different taxonomic levels by using Venn diagrams, where the number of exclusive and shared species, genera and families were compared between methods. With this information, we calculated the complementarity index proposed by Colwell and Coddington (1994), which is expressed as a percentage and gives the value of 0 when the same species are found in both assemblages and 100 when the species are completely different.

\section{Results}

Comparison of the assemblage parameters between methods. We recorded a total of 207 individuals from 17 species, with the Phyllostomidae being the most represented family (Table 1). The total sampling effort was considered to be adequate, as approximately $90 \%$ of the expected number of species for the study site were recorded $(\mathrm{Chao} 1=18, \mathrm{Chao} 2=18.92)$. The greatest total richness and abundance was obtained with ground mist nets, followed by the harp traps and sub-canopy mist nets (Table 1, Fig. 1a).

Total species richness was significantly higher in the ground mist nets ( 8 species) than in the sub-canopy mist nets and the harp traps (each with 6 species). Standardizing the rarefaction curves with 32 individuals, we found no significant differences between these last 2 capture methods (Fig. 1).

The mean richness recorded per night was significantly higher both in harp traps and ground mist nets in relation to sub-canopy mist nets $(\mathrm{H}=5.49, p=0.019$, and $\mathrm{H}=6.34$, $p=0.012$ ), but it was not different between the former 2 methods $(\mathrm{H}=0.39, p=0.53)$. The bat capture rate per night had the same pattern, as it was significantly higher both in the harp traps and the ground mist nets than in the sub-canopy mist nets $(H=15.86, p<0.001$,

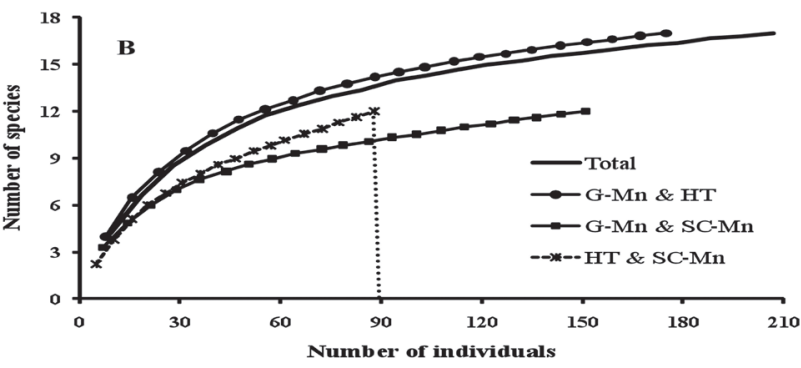

Figure 1. Rarefaction curves for any single method (A), and their combinations (B), in the Dzibilchaltun National Park, Yucatán. * HT= Harp trap, G-Mn= Ground mist nets, SC-Mn= Sub-canopy mist nets. 
Table 1. Total bat captures by species, sampling effort and observed and estimated species richness with 3 capture methods in Dzibichaltun National Park, Yucatán, Mexico

\begin{tabular}{|c|c|c|c|c|}
\hline Family / Species & Ground mist nets & $\begin{array}{c}\text { Sub-canopy mist } \\
\text { nets }\end{array}$ & Harp trap & Trophic guild*** \\
\hline \multicolumn{5}{|l|}{ Phyllostomidae } \\
\hline Micronycteris microtis & 1 & & & GA \\
\hline Diphylla ecaudata & 4 & 2 & & Sang \\
\hline Desmodus rotundus & 7 & & & Sang \\
\hline Glossophaga soricina & 18 & 2 & 12 & Nect \\
\hline Carollia sowelli & 10 & & & Frug \\
\hline Sturnira lilium & 15 & 1 & & Frug \\
\hline Artibeus intermedius & 5 & 1 & & Frug \\
\hline Artibeus jamaicensis & 55 & 25 & & Frug \\
\hline Artibeus lituratus & 1 & & & Frug \\
\hline Dermanura phaeotis & 2 & & & Frug \\
\hline Centurio senex & 1 & & 1 & Frug \\
\hline \multicolumn{5}{|l|}{ Mormoopidae } \\
\hline Pteronotus davyi & & & 20 & AI \\
\hline Pteronotus parnelli & & & 8 & AI \\
\hline Mormoops megalophylla & & & 7 & AI \\
\hline \multicolumn{5}{|l|}{ Vespertilionidae } \\
\hline Rhogeessa tumida & & & 3 & AI \\
\hline Myotis elegans & & 1 & 4 & AI \\
\hline \multicolumn{5}{|l|}{ Natalidae } \\
\hline Natalus stramineus & & & 1 & $\mathrm{AI}$ \\
\hline Individuals captured & 119 & 32 & 56 & \\
\hline Species richness & 11 & 6 & 8 & \\
\hline Sampling effort * & 72 & 72 & 48 & \\
\hline Capture rate $* *$ & 1.17 & 0.44 & 1.65 & \\
\hline Chao 1 & 12.5 & 6 & 9 & \\
\hline Chao 2 & 12.44 & 6 & 9.44 & \\
\hline Completeness (\%) & 96 & 100 & $85-89$ & \\
\hline
\end{tabular}

* Sampling effort $=$ Total mist nets and harp traps

** Capture rate $=$ Number of bats captured per nets or harp traps.

*** Trophic guild= GA: gleaning animalivore, Sang: sanguivores, Nect: nectarivores, Frug: frugivores, AI: aerial insectivores.

and $\mathrm{H}=5.41, p=0.02)$, but the first 2 were not different between themselves $(\mathrm{H}=2.24, p=0.13)$.

The proportion of individuals recorded in each trophic guild was different with each capture method $\left(X^{2}=285\right.$, $p<0.001$ ), with a higher proportion of aerial insectivores in the harp traps and frugivores in the mist nets at both heights (Fig. 2).

Complementarity between methods. Total bat species richness (17 species) was captured using a combination of ground mist nets and harp traps, which was also the combination that had the highest species completeness (92$94 \%$ ), followed by both kinds of mist nets (80-81\%) and sub-canopy mist nets with harp traps (46-80\%) (Fig. 1b).
After standardizing sampling effort to a total of 88 individuals (the lowest abundances recorded combining the capture methods, i.e. sub-canopy mist nets and harp traps), rarefaction curves show that the combination of ground mist nets and harp traps recorded a total richness significantly higher (14 species) than the 2 types of mist nets together (10 species) and the sub-canopy mist net and harp trap together (12 species). We found no significant difference between the last 2 combinations of capture methods (Fig. 1b).

The maximum complementarity between pairs of capture methods was reached using ground mist nets and harp traps, at all taxonomic resolution levels (75\% for 


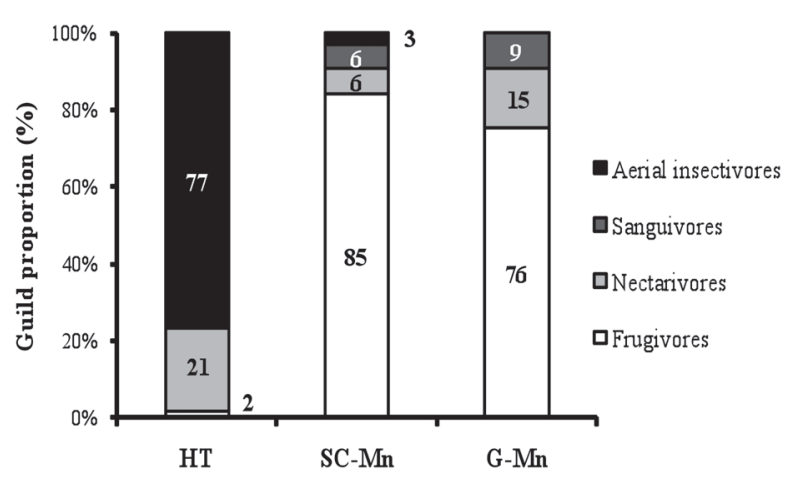

Figure 2. Proportion of bat trophic guilds recorded with each capture method.

families, $86 \%$ for genera and $88 \%$ for species; Fig. 3). Complementarity between harp traps and sub-canopy mist nets was intermediate, while the lowest complementarity was obtained between mist nets placed at different height levels. Interestingly, sub-canopy mist nets did not capture any exclusive bat species, while both ground-level mist nets and harp traps allow the capture of 5 exclusive species each (Fig. 3).

\section{Discussion}

The number of bat species recorded in our study is the second highest among different locations historically sampled in the region, including other natural water bodies and artificial waterholes (swimming pools and ponds) in northern and northwestern Mérida city (Bowles et al., 1990), natural and anthropogenic vegetation types (Cervantes, 2001), and caves and caverns in a local reserve in the south of Mérida city (Ramírez, 2004). The species richness in our study area is only lower than that of a site with a small man-made pond in which 18 species were recorded (Bowles et al., 1990). This indicates that the bat species richness recorded in our study is an adequate representation of the bat diversity present in this region.

The total capture rate recorded in our study (1.08 bats per night per net/trap, BNN/T) is lower than the rate recorded in another study focused completely in cenotes (MacSwiney et al., 2007, 2008), which had a total capture rate of $4.19 \mathrm{BNN} / \mathrm{T}$ and used the same capture methods as we did, but with a different sampling design. This may be explained by the characteristics of vegetation in both studies and the species richness that each site can harbor. Although in MacSwiney et al. (2007) both forested (FOR) and pastureland (PAS) sites with or without cenotes (CEN) had higher bat capture rate than our study site $(\mathrm{FOR}=5.14$; $\mathrm{CENFOR}=5.37 ; \mathrm{PAS}=1.49 ; \mathrm{CENPAS}=2.69 \mathrm{BNN} / \mathrm{T}$,

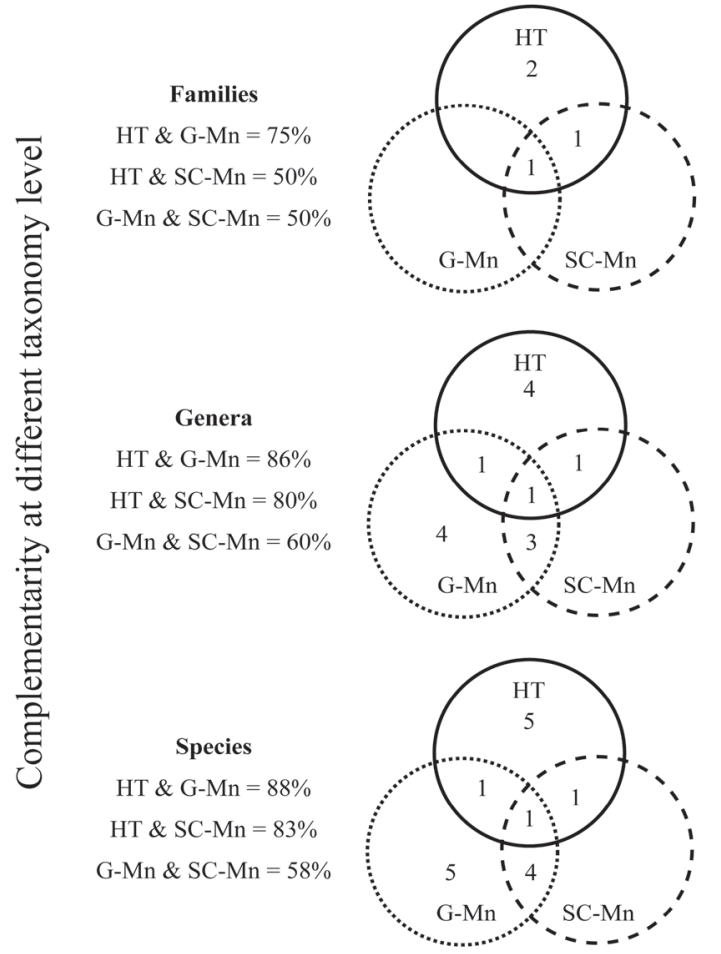

Figure 3. Venn diagrams representing the taxa (families, genera and species) recorded exclusively with each capture method and shared among them. The percentage of complementarity in species composition between the capture methods was calculated using the index described by Colwell and Coddington (1994).

* HT= Harp trap, G-Mn= Ground mist nets, SC-Mn= Sub-canopy mist nets.

respectively), our site had a higher species richness than the PAS (14 species), similar to CENPAS and CENFOR, and lower than FOR (19 species). This indicates that the vegetation associated with the cenote, rather than the water body per se, may have important effects not only on bat abundance (MacSwiney et al., 2007), but also on bat species richness independently of differences in bat abundance.

Even if we combine the results of 3 capture methods, we failed to capture 2 species previously reported at the study site (Molossus ater and Eptesicus furinalis; Bowles et al., 1990). Indirect methods can improve the completeness of a bat inventory as they are able to record hard-to-capture species (O'Farrell and Gannon, 1999; Portfors et al., 2000; MacSwiney et al., 2006; Larsen et al., 2007). In a later occasional sample in the site, we recorded these species with ultrasonic detectors, as well as other insectivorous species that fly over the canopy, such as molossids and emballonurids (Pech et al., 2010).

Other factors that could improve the efficiency of bat species inventories are an increase in sampling effort each 
night, as well as an increase in the frequency of net/trap visits (checks) during the night. Studies with different sampling schedules have demonstrated that revising nets/ traps over shorter time periods $(<10 \mathrm{~min})$ can potentially increase the bat capture rate per night (MacCarthy et al., 2006), and that keeping the nets open all night can increase the total accumulated species richness (Esbérard and Bergallo, 2008). Such strategies could increase the punctual alpha diversity recorded.

Comparison of capture methods. As in previous studies, none of the individual methods we used captured all of the bat species at the site (Simmons and Voss, 1998; Portfors et al., 2000; Bernard, 2001; Sampaio et al., 2003; Flaquer et al., 2007; MacSwiney et al., 2007). However, groundlevel mist nets may be considered the best choice for the inventory of phyllostomid bats, the dominant group in the Neotropics, as they are the most catchable bats when using this technique (Fenton et al., 1992; Simmons and Voss, 1998; Portfors et al., 2000; Larsen et al, 2007). Indeed, this method allowed us to capture all of the expected species within this family.

In this study the use of harp traps enriched the overall species inventory by registering 6 insectivorous species from 3 different families. These species were probably attracted to the cenote because it is a source of water and insects throughout the year (Mickevièienë and Mickevièius, 2001; MacSwiney et al., 2009).

The lower species richness and capture rate recorded in the sub-canopy mist nets could be due to the type and height of vegetation found at the study site that does not permit a great contrast between the vegetation strata. At sites with greater maturity of vertical and horizontal vegetation, it has been demonstrated that this technique can efficiently increase the completeness of an inventory (Simmons and Voss, 1998; Bernard, 2001; Kalko and Handley, 2001), including other vegetation types in the same region (MacSwiney et al., 2007).

Complementarity between capture methods. Our results demonstrate that the combined use of different capture methods is necessary to obtain more complete inventories of bats, as different capture methods can capture different species (Portfors et al., 2000; Kalko and Handley, 2001; Flaquer et al., 2007; MacSwiney et al., 2007). In some cases this allows for sufficient levels of inventory completeness, validating the extent of inferences about the bat assemblage as a whole (Clarke et al., 2005). In our study, ground mist nets were the most appropriate for recording phyllostomid frugivores and nectarivores. Harp traps were the most appropriate for insectivorous bats of other families, as other studies have found in the Paleotropics (Francis, 1989; Kingston et al., 2003) and in the Neotropics (Clarke et al., 2005; MacSwiney et al., 2008). This differential bat capture success is largely a result to the differences in flying mode and habitat use of the bat species due their diverse feedings requirements (Kalko, 1998). Also, the different location where nets and traps were placed can be another source of variation (Carroll et al., 2002).

In conclusion, our results indicate that for comparable data in the Yucatán lowland tropical dry forest, a program of rapid, inexpensive and easy-to-carry inventories can be achieved if bat diversity studies are taxonomically restricted to the family Phyllostomidae, which is reliably captured with ground-level mist nets. However, if the taxonomic interest is the order Chiroptera as a whole, the most efficient combination of capture methods is the simultaneous use of ground-level mist nets and harp traps. Simultaneous placement of ground level and sub-canopy mist nets does not provide an efficient sampling strategy given the low complementarity between these capture techniques.

\section{Acknowledgments}

This study was made possible by a doctoral grant (Reg. 190551) awarded to the first author by the CONACyT. The field work was partly financed by the FOSERMARNAT-2004-01-180 project, carried out by the Cuerpo Académico Bioecología Animal of the UADY and by the INECOL. We thank the INAH and the personnel at the Dzibilchaltun National Park for the facilities provided, especially Don Fernando, and all of those who helped us during the field work. We thank C. MacSwiney for the material provided during the field period, and $\mathrm{M}$. A. Munguía-Rosas and V. Sosa for their comments on a previous version of this manuscript. J. Dunn translated the article from the original in Spanish. L. Ruiz-Ruiz helped with edition of figures.

\section{Literature cited}

Bernard, E. 2001. Vertical stratification of bat communities in primary forests of Central Amazon, Brazil. Journal of Tropical Ecology 17:115-126.

Berry, N., W. O'Connor, M. Holderied and G. Jones. 2004. Detection and avoidance of harp traps by echolocating bats. Acta Chiropterologica 6:335-346.

Bowles, J., P. Heideman and K. Erickson. 1990. Observations on six species of free-tailed bats (Molossidae) from Yucatán, Mexico. Southwestern Naturalist 35:151-157.

Bradshaw, P. A. 1996. The physical nature of vertical forest habitat and its importance in shaping bat species assemblage. In Bats and forest symposium, R. M. R. Barclay and R. M. Brigham (eds.). British Columbia Ministry of Forest, Victoria. p. 199-212. 
Carroll, S., T. C. Carter and G. Feldhamer. 2002. Placement of nets for bats: effects on perceived fauna. Southeastern Naturalist 1:193-198.

Cervantes, M. C. 2001. Estructura y diversidad de la comunidad de quirópteros en tres sitios con perturbación antropogénica en la Reserva Ecológica Cuxtal, Yucatán, México. Thesis, Facultad de Medicina Veterinaria y Zootecnia, Universidad Autónoma de Yucatán. México. 45 p.

Clarke, F. M., L.V. Rostant and P. A. Racey. 2005. Life after logging: post-logging recovery of a neotropical bat community. Journal of Applied Ecology 42:409-420.

Colwell, R. K. 2005. StimateS: Statistical estimation of species richness and shared species from samples. Version 7.5.

Colwell, R. K. and J. A. Coddington. 1994. Estimating terrestrial biodiversity through extrapolation. Philosophical Transactions: Biological Sciences 345:101-118.

Duch, G. 1988. La conformación territorial del Estado de Yucatán. Universidad Autónoma Chapingo. México. 427 p.

Esbérard, C. E. and H. G. Bergallo. 2008. Bat richness using different sampling methodologies in southeastern Brazil. Revista Brasileira de Zoologia 25:67-73.

Fenton, M. B., L. Acharya, D. Audet, M. B. Hickey, C. Merriman, M. K. Obrist, D. M. Syme and B. Adkins. 1992. Phyllostomyd bats (Chiroptera: Phyllostomidae) as indicators of habitat disruptions in the Neotropics. Biotropica 24:440-446.

Fenton, M. B., S. Bouchard, M. Vonhof and J. Zigouris. 2001. Time-expansion and zero-crossing period meter system present significantly different views of echolocation calls of bats. Journal of Mammalogy 82:721-727.

Findley, J. S. and D. E. Wilson. 1983. Are bats rare in tropical Africa? Biotropica 15:299-303.

Flaquer, C., I. Torre and A. Arrizabalaga. 2007. Comparison of sampling methods for inventory of bat communities. Journal of Mammalogy 88:526-533.

Francis, C. M. 1989. A comparison of mist nets and two types of harp traps for capturing bats. Journal of Mammalogy 70:865870 .

Johnson, J., M. Menzel, J. Edwards and M. Ford. 2002. A comparison of 2 acoustical bat survey techniques. Wildlife Society Bulletin 30:931-936.

Kalcounis, M. C., K. A. Hobson, R. A. Brigham and K. R. Hecker. 1999. Bat activity in the boreal forest: Importance of stand type and vertical strata. Journal of Mammalogy 80:673-682.

Kalko, E. K. V. 1998. Organization and diversity of tropical bat communities through space and time. Zoology 101:281-297.

Kalko, E. K. V. and C. O. Handley, Jr. 2001. Neotropical bats in the canopy: diversity, community structure and implications for conservation. Plant Ecology 153:319-333.

Kingston, T., C. M. Francis, Z. Akbar and T. H. Kunz. 2003. Species richness in an insectivorous bat assemblage from Malaysia. Journal of Tropical Ecology 19:67-79.

Kuenzi, A. J. and M. L. Morrison. 1998. Detection of bats by mist-nets and ultrasonic sensors. Wildlife Society Bulletin 26:307-311.

Larsen, R. J., K. A. Boegler, H. H. Genoways, W. P. Masefield, R. A. Kirsch and S. C. Pedersen. 2007. Mist netting bias, species accumulation curves, and the rediscovery of two bats on Montserrat (Lesser Antilles). Acta Chiropterologica 9:423-435.

MacCarthy, K. A., T. C. Carter, B. J. Steffen and G. A. Feldhamer. 2006. Efficacy of the mist-net protocol for Indiana bats: A video analysis. Northeastern Naturalist 13:25-28.

MacSwiney, M. C., B. Bolívar, F. M. Clarke and P. A. Racey. 2006. Nuevos registros de Pteronotus personatus y Cynomops mexicanus (Chiroptera) en el estado de Yucatán, México. Revista Mexicana de Mastozoología 10:102-109.

MacSwiney, M. C., P. Vilchis, F. M. Clarke and P. A. Racey. 2007. The importance of cenotes in conserving bat assemblages in the Yucatán, Mexico. Biological Conservation 136:499-509.

MacSwiney, M. C., F. M. Clarke and P. A. Racey. 2008. What you see is not what you get: the role of ultrasonic detectors in increasing inventory completeness in Neotropical bat assemblages. Journal of Applied Ecology 45:1364-1371.

MacSwiney, M. C., B. Bolivar, F. M. Clarke and P. A. Racey. 2009. Insectivorous bat activity at cenotes in the Yucatán Peninsula, Mexico. Acta Chiropterologica 11:139-147.

Magurran, A. 2004. Measuring biological diversity. Blackwell Publishing. Great Britain. 256 p.

Medellín, R. A. 1993. Estructura y diversidad de una comunidad de murciélagos en el trópico húmedo mexicano. In Avances en el estudio de los mamíferos de México, R. A. Medellín and G. Ceballos (eds.). Asociación Mexicana de Mastozoología, México, p. 333-350.

Medellín, R., M. Equihua and M. A. Amín. 2000. Bat diversity and abundance as indicators of disturbance in Neotropical rainforest. Conservation Biology 14:1666-1675.

Mickevièienë, I. and E. Mickevièius. 2001. The importance of various habitat types to bats (Chiroptera: Vespertilionidae) in Lithuania during the summer period. Acta Zoologica Lituanica 11:3-14.

Milne, D. J., M. Armstrong, A. Fisher, T. Flores and R. Pavey. 2004. A comparison of three survey methods for collecting bat echolocation calls and species accumulation rates from nightly Anabat recordings. Wildlife Research 31:57-63.

Mora, E. C., S. Macías, D. Rojas, A. Rodríguez, I. Quiñónez, A. García, A. Cádiz and B. Boburg. 2002. Aplicación de métodos bioacústicos y convencionales en la caracterización de la comunidad de murciélagos de la Cueva del Indio, Tapaste, la Habana, Cuba. Revista Biología 16:159-166.

Morrison, D. W. 1978. Lunar phobia in a Neotropical fruit bat, Artibeus jamaicensis (Chiroptera: Phyllostomidae). Animal Behavior 26:852-855.

O'Farrell, M. J. and W. L. Gannon. 1999. A comparison of acoustic versus capture techniques for the inventory of bats. 
Journal of Mammalogy 80:24-30.

Pech-Canche, J. M., C. MacSwiney G. and E. Estrella. 2010. Importancia de los detectores ultrasónicos para mejorar los inventarios de murciélagos Neotropicales. Therya 1:221228.

Pedersen, S. C., H. H. Genoways, M. N. Morton, G. G. Kwiecinski and S. E. Courts. 2005. Bats of St. Kitts (St. Christopher), Northern Lesser Antilles, with comments regarding capture rates of Neotropical bats. Caribbean Journal of Science 41:744-760.

Portfors, C. V., M. B. Fenton, L. M. de S. Aguiar, J. E. Baumgarten, M. J. Vonhof, S. Bouchard, D. M. de Faria, W. A. Pedro, N. I. L. Tauntenbach and M. Zortea. 2000. Bats from Fazenda intervales, southeastern Brazil - species account and comparison between different sampling methods. Revista Brasileira de Zoologia 17:533-538.

Ramírez, V. 2004. Diversidad de murciélagos en cuevas y cenotes de la reserva Ecológica Cuxtal, Yucatán, México. Thesis, Facultad de Medicina Veterinaria y Zootecnia, Universidad Autónoma de Yucatán. México. 47 p.

R Development Core Team. 2008. R: A language and environment for statistical computing. $\mathrm{R}$ Foundation for Statistical Computing, Vienna, Austria. ISBN 3-900051-07-0, URL http://www.R-project.org. 01.II.2010.

Rice, W. R. 1989. Analyzing tables of statistical tests. Evolution 43:223-225.

Sampaio, E. M., E. K. V. Kalko, E. Bernard, B. Rodriguez-
Herrera and C.O. Handley Jr. 2003. A biodiversity assessment of bats (Chiroptera) in a tropical lowland rainforest of Central Amazonia, including methodological and conservation considerations. Studies on Neotropical Fauna and Environment 38:17-31.

SECOL. 1998. Ficha técnica del Plan de Manejo del Parque Nacional Dzibilchaltun. Gobierno del Estado de Yucatán, México.

Simmons, N, B. and R. S. Voss. 1998. The mammals of Paracou, French Guiana: A neotropical lownland rainforest fauna part 1. Bats. Bulletin of the American Museum of Natural History 237:1-219.

Weller, T. and C. Zabel. 2002. Variation in bat detections due to detector orientation in a forest. Wildlife Society Bulletin 30:922-930.

Willott, S. J. 2001. Species accumulation curves and the measure of sampling effort. Journal of Applied Ecology 38:484-486.

Wilson, D. E., R. Cole, J. Nichols, R. Rudran and M. Foster. 1996. Measuring and monitoring biological diversity: Standard methods for mammals. Smithsonian Institution Press. Washington, USA. 480 p.

Winhold, L. and A. Kurta. 2008. Netting surveys for bats in the northeast: differences associated with habitat, duration of netting, and use of consecutive nights. Northeastern Naturalist 15:263-274.

Zar, J. 1999. Biostatistical analysis. 4 ed. Prentice Hall. USA. $663 \mathrm{p}$. 